\title{
Influence of continental advection on aerosol characteristics over Bay of Bengal (BoB) in winter: results from W-ICARB cruise experiment
}

\author{
S. K. Kharol ${ }^{1,2}$, K. V. S. Badarinath ${ }^{1}$, D. G. Kaskaoutis ${ }^{3}$, A. R. Sharma ${ }^{1}$, and B. Gharai ${ }^{1}$ \\ ${ }^{1}$ Atmospheric Science Section, National Remote Sensing Centre, Dept. of Space-Govt. of India, Balanagar, \\ Hyderabad - 500 625, India \\ ${ }^{2}$ Department of Physics and Atmospheric Science, Dalhousie University, Halifax, Canada \\ ${ }^{3}$ Research and Technology Development Centre, Sharda University, Greater Noida, NCR - 201 306, India
}

Received: 21 November 2010 - Revised: 18 July 2011 - Accepted: 31 July 2011 - Published: 24 August 2011

\begin{abstract}
The transport of aerosols and pollutants from continental India to the adjoining oceanic areas is a major topic of concern and several experimental campaigns have been conducted over the region focusing on aerosol characteristics and their climate implications. The present study analyzes the spectral aerosol optical depth (AOD) variations over Bay of Bengal $(\mathrm{BoB})$ during Winter-Integrated Campaign for Aerosols, gases and Radiation Budget (W-ICARB) from 27 December 2008 to 30 January 2009 and investigates the influence of the adjoining landmass to the marine aerosol field. High $\mathrm{AOD}_{500}$ values $(>0.7)$ occurred over northern BoB due to outflow of aerosols and pollutants from the densely populated Indo-Gangetic Plains (IGP); low AOD $500(0.1-0.2)$ was observed in central and southern $\mathrm{BoB}$, far away from the mainland. The Angstrom exponent " $\alpha$ " was observed to be high $(>1.2)$ near coastal waters, indicating relative abundance of accumulation-mode continental aerosols. On the other hand, over southern $\mathrm{BoB}$ its values dropped below 0.7. National Center for Environmental Prediction (NCEP) reanalysis data on winds at 850 and $700 \mathrm{hPa}$, along with airmass trajectories calculated using Hybrid Single Particle Lagrangian Integrated Trajectory (HYSPLIT) model, suggested transport of continental aerosols from central and northern India over the BoB. On the other hand, when the ship was crossing the eastern $\mathrm{BoB}$, the aerosol loading was strongly affected by air-masses originating from Southeast Asia, causing an increase in AOD and $\alpha$. Biomass-burning episodes over the region played an important role in the observed aerosol properties. Terra/Aqua Moderate Resolution Imaging Spectroradiometer (MODIS) AOD $_{550}$ and cruise measured $\mathrm{AOD}_{550}$ showed good agreement $\left(R^{2}=0.86\right.$ and 0.77 ,
\end{abstract}

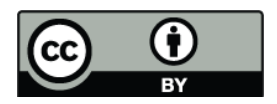

Correspondence to: S. K. Kharol (shaileshan2000@yahoo.co.in) respectively) over $\mathrm{BoB}$, exhibiting similar $\mathrm{AOD}$ and $\alpha$ spatiotemporal variation.

Keywords. Atmospheric composition and structure (Aerosols and particles)

\section{Introduction}

Tropospheric aerosols affect the radiation budget by scattering and absorbing the incoming solar radiation (direct effect) and by modifying the cloud albedo and droplet size distribution, thereby changing the radiative properties and lifetime of clouds (indirect effect) and suppressing precipitation (IPCC, 2007). The influence of aerosols on climate is much more complex than those of greenhouse gases because of different sources and production mechanisms and short atmospheric residence times, from less than a day to more than a week. Thus, the radiative forcing and the resulting climate impact due to atmospheric aerosols remain largely uncertain, primarily due to inadequate data representing the spatio-temporal heterogeneity of the aerosol properties and to the poor understanding of the aerosol-cloud interactions (Patadia et al., 2008). More systematic measurements of atmospheric aerosol properties, together with numerical modeling and data assimilation, are needed to reduce the uncertainties (Diner et al., 2004; Yu et al., 2006; Mian Chin et al., 2009).

Over the Indian subcontinent and surrounding oceanic regions, a number of observational campaigns, viz., Arabian Sea Monsoon Experiment (ARMEX), Indian Ocean Experiment (INDOEX), Land Campaigns (LC) LC-I and LC-II, and Integrated Campaign for Aerosols, gases and Radiation Budget (ICARB) were conducted to investigate the role of aerosols in altering the atmospheric radiation budget (e.g.

Published by Copernicus Publications on behalf of the European Geosciences Union. 




Fig. 1. The cruise track of Sagar Kanya 254 in the Bay of Bengal during the W-ICARB, 27 December 2008-30 January 2009. The arrow shows the track of the ship while the circles show the position of the ship at 10:30 LST for each day. The entire BoB is divided in 5 sub-regions, namely (a) west, (b) north, (c) east, (d) central, and (e) south.

Ramanathan et al., 2001; Moorthy et al., 2005, 2008; Jayaraman et al., 2006). Despite the above campaigns, other few field experiments were limited to cruises along the Indian coasts and coastal northern BoB (e.g. Sumanth et al., 2004; Vinoj et al., 2004; Ganguly et al., 2005) and focused mainly on columnar aerosol optical depth (AOD) and ambient total mass concentration measurements. The first ICARB was conducted during the pre-monsoon season of March-May 2006 over the Indian subcontinent and adjoining oceanic regions, e.g. Bay of Bengal (BoB), Northern Indian Ocean (NIO), and Arabian Sea (AS). The main results of this campaign have been highlighted in numerous studies included in the special issue of Journal of Earth System Science (Volume 117, S1, July 2008). However, dedicated ship-borne measurements to explore the aerosol characteristics in the entire $\mathrm{BoB}$ were almost nonexistent, since the eastern $\mathrm{BoB}$ had remained fairly unexplored during ICARB-06. In continuation of the previous campaign, ICARB during winter season (W-ICARB) was conducted from 27 December 2008 to 30 January 2009 over Indian mainland and BoB aiming to explore the $\mathrm{BoB}$ in finer detail, including the northern, eastern part and also NIO, focusing on the physical and optical properties of atmospheric aerosols, trace gases and aerosol chemistry over the region.

In the present study, we have analyzed the variations in spectral AOD and aerosol optical properties over BoB during W-ICARB, focusing on the influence of continental fluxes over the oceanic area using columnar aerosol properties. Sinha et al. (2011b) and Sreekanth et al. (2011) analyzed the vertical structure of aerosols over the Marine Atmospheric Boundary Layer (MABL) via balloon and aircraft measurements, respectively, while Sinha et al. (2011a) focused on aerosol concentrations and particle size at the sea level and Kumar et al. (2010) on aerosol chemical composition. In a recent study, Kaskaoutis et al. (2011) aimed at classifying the aerosols over BoB into specific types, focusing also on the modification of aerosol processes in the marine atmosphere. Their results highlighted a large anthropogenic (fine-mode) aerosol component over nearly the whole BoB. The present work aims at identifying the sources for such large anthropogenic aerosol component, either originated from continental India or Southeast Asia - two regions that seem to produce aerosols of different types and characteristics. BoB, being surrounded by the rapidly developing Southeast Asian regions, provides an excellent laboratory to analyze the continental fluxes. Systematic sun-photometric measurements using MICROTOPS-II (MT) were performed over the oceanic research vessel (Sagar Kanya), spanning 35 days and covering the whole BoB. Furthermore, Terra and Aqua MODIS observations were used for comparison with the ship measurements. In contrast to the pre-ICARB campaigns, the large spatial coverage allows us to highlight the highly heterogeneous aerosol field, both in spatial and temporal domains, and to provide some useful information about the continental (Indian and Southeast Asian) influence. Section 2 provides information about the cruise track around $\mathrm{BoB}$, the data set used are described in Sect. 3, while Sect. 4 presents the meteorological conditions during the cruise campaign. The results are discussed in Sect. 5, while Sect. 6 summarizes the main conclusions.

\section{W-ICARB cruise track}

The cruise track during the W-ICARB campaign is shown in Fig. 1. The arrowheads denote the direction of the ship movement, while the red circles show the mean position of the ship at 10:30 h (Local Time) on each day. The ship started from Chennai port $\left(13.1^{\circ} \mathrm{N}, 80.2^{\circ} \mathrm{E}\right)$ on 27 December 2008 , and during its return journey, it passed Sri Lanka on 28 January 2009 and returned back to Kochi $\left(9.6^{\circ} \mathrm{N}, 76.1^{\circ} \mathrm{E}\right)$ at AS on 30 January 2009. The particular configuration of the cruise track (Fig. 1) enabled measurements on the coastal waters adjoining the anthropogenically-dominated mainland and far off oceanic regions in rapid succession (Moorthy et al., 2010). This provided a nearly homogeneous spatially gridded aerosol database within a time span of about a month, during which the aerosol characteristics are considered to be statistically invariant (Moorthy et al., 2009). This was also corroborated by the prevailing meteorology, which was devoid of any major synoptic weather systems, such as cyclones, depressions, or extensive cloud cover during the measuring period. 


\section{Datasets and methodology}

High temporal resolution ( $\sim 10 \mathrm{~min})$ measurements of directbeam solar radiation were made using two (sun-photometer and ozonometer) handheld MICROTOPS-II (Solar Light Company, USA). The one provides the AOD at 5 channels $(380,440,500,675$, and $870 \mathrm{~nm})$, while the other the AOD at $1020 \mathrm{~nm}$, the columnar water vapor and the column ozone, using three UV and two IR bands, one of them being $1020 \mathrm{~nm}$. The sun photometer works on the principle of measuring surface-reaching solar radiation intensity at specified wavelength bands and calculates corresponding optical depths by knowing the respective radiation intensities at top of atmosphere (TOA), using its internal calibration. The Full Width at Half Maximum (FWHM) bandwidth is $2.4 \pm 0.4 \mathrm{~nm}$ at $380 \mathrm{~nm}$ channel and $10 \pm 1.5$ at the other channels. The accuracy of the sun-targeting angle is better than $0.1^{\circ}$. The errors in the AOD estimation could result from diffuse radiation entering the optical channel, computation error in relative air mass, calibration coefficient variation with time, and uncertainty in the optical depths due to Rayleigh scattering and absorption by $\mathrm{O}_{3}, \mathrm{NO}_{2}$, and water vapor (Shaw, 1976). Furthermore, we have applied the Cachorro et al. (2004) technique of correction to each wavelength for eliminating the diurnal artifact of the AOD. The absolute error in the derived AODs is about \pm 0.03 (Morys et al., 2001), with larger values in the UV. The MT instrument was factory calibrated at regular interval, while more details about the measurement protocol and accuracy of the AOD retrievals can be found in Kaskaoutis et al. (2011).

Ship-borne measurements of air temperature $(T)$, atmospheric pressure, relative humidity (RH), wind speed (WS), and direction have also been carried out on an hourly basis. In addition, sea surface temperature (SST) measurements were taken using the bucket thermometer from a few centimeters below the sea surface. The measured WS was corrected for the velocity of the ship using the method proposed by Smith et al. (1999). A global positioning system (GPS) onboard provided continuous information on time and position of the ship.

The MODIS AOD 550 and $\alpha_{550-865}$ (over ocean) values were also used to analyze the spatial distribution of the columnar aerosol properties. The MODIS data correspond to collection 5 (C005) level 3 (Levy et al., 2007) from both Terra and Aqua satellites. The level 3 was selected in order to cover the whole movement of the ship on each day. Thus, the MODIS data correspond to the averaged value of some pixels (depending on the daily ship movement) covering an area ranging from $100 \times 100 \mathrm{~km}$ to $300 \times 300 \mathrm{~km}$ along the ship track. The MT aerosol measurements in a time interval of $\pm 30 \mathrm{~min}$ around the MODIS overpass were used for the comparison with the MODIS data. It was found that the use of level $2(10 \times 10 \mathrm{~km})$ MODIS data are strongly correlated with the level 3 ones $(R=0.92)$ for both Terra and Aqua (Sinha et al., 2011a).
In addition, we used Cloud-Aerosol Lidar and Infrared Pathfinder Satellite Observation (CALIPSO) images for the backscatter coefficient at 532 and the depolarization ratio in a specific day of the cruise in order to present the intense outflow of aerosols and pollutants from Indian sub-continent towards BoB. CALIPSO provides new insight on the role of atmospheric aerosols and clouds in regulating Earth's weather, climate, and air quality by providing their vertical distribution. As part of the A-train satellite constellation, CALIPSO has a $98^{\circ}$-inclination orbit and flies at an altitude of $705 \mathrm{~km}$, and can observe aerosols over bright surfaces and beneath thin clouds with vertical resolution of $30 \mathrm{~m}$. The CALIPSO payload consists of three instruments: the Cloud-Aerosol Lidar with Orthogonal Polarization (CALIOP), an Imaging Infrared Radiometer (IIR), and a moderate spatial resolution Wide Field-of-view Camera (WFC). CALIOP provides profiles of aerosols at 532 and $1064 \mathrm{~nm}$, as well as two orthogonal (parallel and perpendicular) polarization components at $532 \mathrm{~nm}$. A detailed description about CALIPSO instruments, operation, and measurements can be found elsewhere (Powell et al., 2009).

In order to identify the source regions as well as the transport pathways of the air parcels arriving over $\mathrm{BoB}$ during the cruise campaign, we have used the Hybrid Single Particle Lagrangian Integrated Trajectory (HYSPLIT) model. Fivedays back trajectories at 3 atmospheric levels are considered: (a) $500 \mathrm{~m}$ (within the MABL), (b) $1500 \mathrm{~m}$ (above the MABL but below the trade wind inversion), and (c) $3000 \mathrm{~m}$ (in the lower free troposphere).

\section{Prevailing meteorology during W-ICARB}

The NCEP/NCAR reanalysis meridional and zonal wind fields at the pressure levels 850 and $700 \mathrm{mb}$ have been used to ascertain the synoptic meteorological conditions during the study period. Figure 2 shows the mean composite vector wind at 850 and $700-\mathrm{mb}$ levels, respectively over South Asia for the period of 27 December 2008 to 30 January 2009. The arrowheads show the wind direction and the length of arrow corresponds to the mean wind speed, which is also represented by the colored scale. The winds at $850 \mathrm{mb}$ were below $\sim 4 \mathrm{~m} \mathrm{~s}^{-1}$ over continental India, having larger intensities over BoB, mainly over its southern parts. The stronger winds over southern BoB may be responsible for the production of coarse sea-salt aerosols (Kaskaoutis et al., 2011; Sinha et al., 2011a). The low level anticyclone prevailed over the Indian mainland led to a continental outflow from IndoGangetic Plains (IGP) over the northwestern BoB. In further contrast, the eastern and southern parts of $B o B$ were under the influence of easterlies from Southeast Asia. Note also the very low winds, indicating absence of continental advection in northeastern BoB (close to Myanmar coast) where the AODs are the lowest (see following sections). Similar synoptic wind pattern prevailed at $700 \mathrm{mb}$, even composed by 

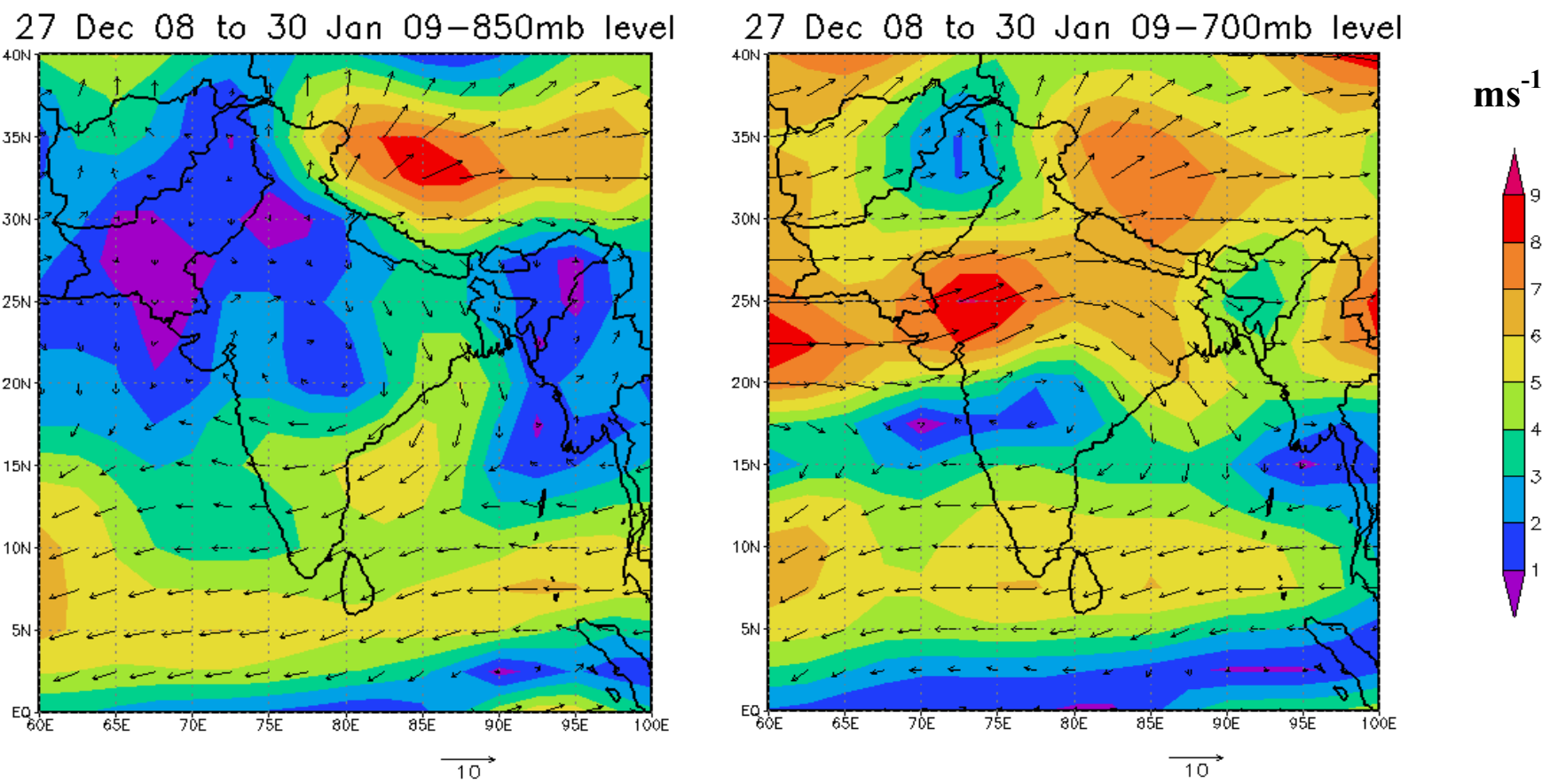

Fig. 2. Mean synoptic wind patterns (in $\mathrm{m} \mathrm{s}^{-1}$ ) at $850 \mathrm{mb}$ (left) and $700 \mathrm{mb}$ (right) over South Asia during W-ICARB (27 December 2008 to 30 January 2009). The data were obtained from NCEP-NCAR reanalysis.
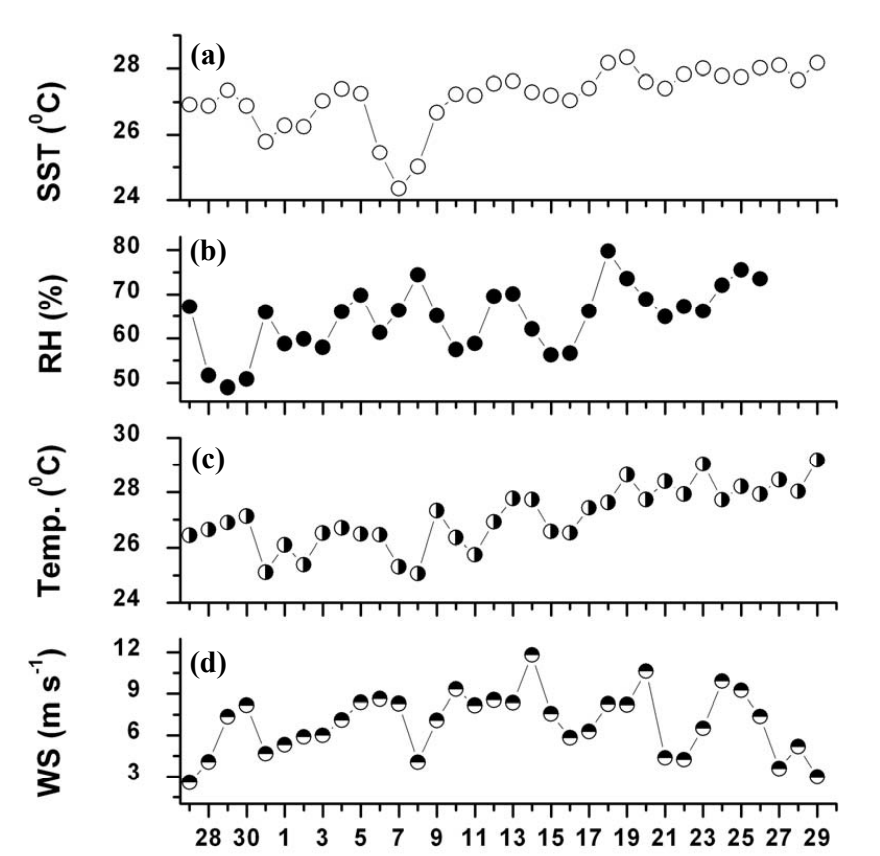

Date (December, 2008 - January, 2009)

Fig. 3. Day-to-day variation of (a) sea surface temperature (SST), (b) relative humidity $(\mathrm{RH})$, (c) air temperature and, (d) wind speed (WS) over BoB during W-ICARB. stronger $\left(>7 \mathrm{~m} \mathrm{~s}^{-1}\right)$ northwesterly winds over the northern BoB.

Measurements of several meteorological parameters during the cruise campaign were taken using multiple sensors, which were kept at $\sim 10 \mathrm{~m}$ a.m.s.l. onboard the ship. Most of the days were cloudless or partly cloudy, while the average convective mixed layer height ranged from $\sim 100 \mathrm{~m}$ to $\sim 1.7 \mathrm{~km}$ with a mean of $\sim 710 \mathrm{~m}$ as determined via radiosonde temperature profiles. Figure 3a-d shows the daily mean variation of SST, RH, $T$, and WS, respectively, during W-ICARB. The SST was varying between $24^{\circ} \mathrm{C}$ and $28^{\circ} \mathrm{C}$. As expected, the lowest SST values were observed in the northern BoB (31 December 2008, 7 January 2009) and the highest in the south BoB and NIO (last days of the cruise), creating a pronounced latitudinal gradient. The $\mathrm{RH}$ was ranging between $49-80 \%$, with the lowest values $(\sim 50 \%)$ to be observed on the first days of the cruise (28-30 December), probably affected by the drier continental air masses. Low $\mathrm{RH}$ values were also observed in the eastern $\mathrm{BoB}(11,15-16$ January 2009), while in some parts of north (e.g. 7 January) and especially in south BoB, the RH was above $70-75 \%$. During the cruise campaign the daily mean air temperature (T) varied from $24.5^{\circ} \mathrm{C}$ to $29.3^{\circ} \mathrm{C}$, while the lowest and highest values were observed in the northern BoB (31 December, 7-8 January) and in the southern parts (last cruise days), respectively. The WS showed considerable fluctuations during the cruise period, ranging from low $\left(\sim 2 \mathrm{~m} \mathrm{~s}^{-1}\right)$ to high $\left(\sim 12 \mathrm{~m} \mathrm{~s}^{-1}\right)$ values. The mean synoptic wind pattern 
over BoB comprised of northwesterly winds $\left(<7 \mathrm{~m} \mathrm{~s}^{-1}\right)$ over the northern and western $\mathrm{BoB}$, while stronger easterly winds $\left(>8 \mathrm{~m} \mathrm{~s}^{-1}\right)$ prevailed over eastern and southern BoB.

\section{Results and discussion}

\subsection{Aerosol optical properties over BoB}

Spectral AOD in all the clear-sky days were carried out using MICROTOPS-II sun photometer at five wavelengths (i.e. $380,440,500,675$, and $870 \mathrm{~nm}$ ) in $\sim 10$-min time intervals. Figure $4 a-c$ shows the spatial distribution of $\mathrm{AOD}_{500}$, Angstrom exponent $\alpha$ and turbidity coefficient $\beta$, respectively. These figures have the disadvantage of providing a spatial distribution where the measurements correspond to a fixed location at a defined time interval. However, it was found that no significant temporal variability exists over the time period of one month able to strongly affect the presented spatial distributions. The $\mathrm{AOD}_{500}$ exhibits large dayto-day variation with a sharp latitudinal gradient and similar spatial distribution to that observed in the pre-monsoon ICARB-06 campaign (e.g. Moorthy et al., 2008). Thus, the present results show that the continental outflow over BoB is also significant in winter, whereas the aerosol field in the two seasons (winter and pre-monsoon) is composed of different types, having larger coarse-mode fraction and aerosols of desert origin in pre-monsoon (Kalapureddy and Devara, 2008). Very high $\operatorname{AOD}_{500}(0.7$ to $>1.0)$ occurs close to the northeastern Indian coast due to direct influence of the coastal urban centers and the long-range transport of continental aerosols. Lower $\mathrm{AOD}_{500}$ values $(0.1-0.2)$ occur in central $\mathrm{BoB}$, far away from the coasts, and in a small area in the northeastern part of BoB close to Myanmar coast. The latter is somewhat unexpected, but the air masses were rather clear (fast moving from the west and/or of marine origin) when the ship was cruising in this area. $\mathrm{AOD}_{500}$ values ranging from 0.4-0.6 and 0.2-0.5 are observed over eastern and southern BoB, respectively. A mean $\mathrm{AOD}_{500}$ of $0.41 \pm 0.14$ over coastal-central $\mathrm{BoB}$ was reported during a limited cruise campaign in February 2003 (Vinoj et al., 2004); more specifically, they found mean $\mathrm{AOD}_{500}$ of $0.54 \pm 0.05$ near the coast and $0.30 \pm 0.05$ in central $\mathrm{BoB}$, which are very close to the present results. The mean $\mathrm{AOD}_{500}$ during W-ICARB was found to be $0.38 \pm 0.21$, thus exhibiting large spatial heterogeneity. This mean value is comparable in magnitude with that $(0.36 \pm 0.12)$ found over BoB during ICARB-06 (Kalapureddy and Devara, 2008). The little higher winter value (this study) is mainly attributed to some extreme $\mathrm{AOD}_{500}$ measured over northwest BoB on 2 January $(1.53 \pm 0.17)$. On that day the sun photometer observations were limited only in morning hours (till $\sim 11: 30 \mathrm{LST}$ ) and were not used from other studies conducted over the region (e.g. Moorthy et al., 2010). The weather conditions in early morning were hazy with the formation of thin clouds at noon. Based on
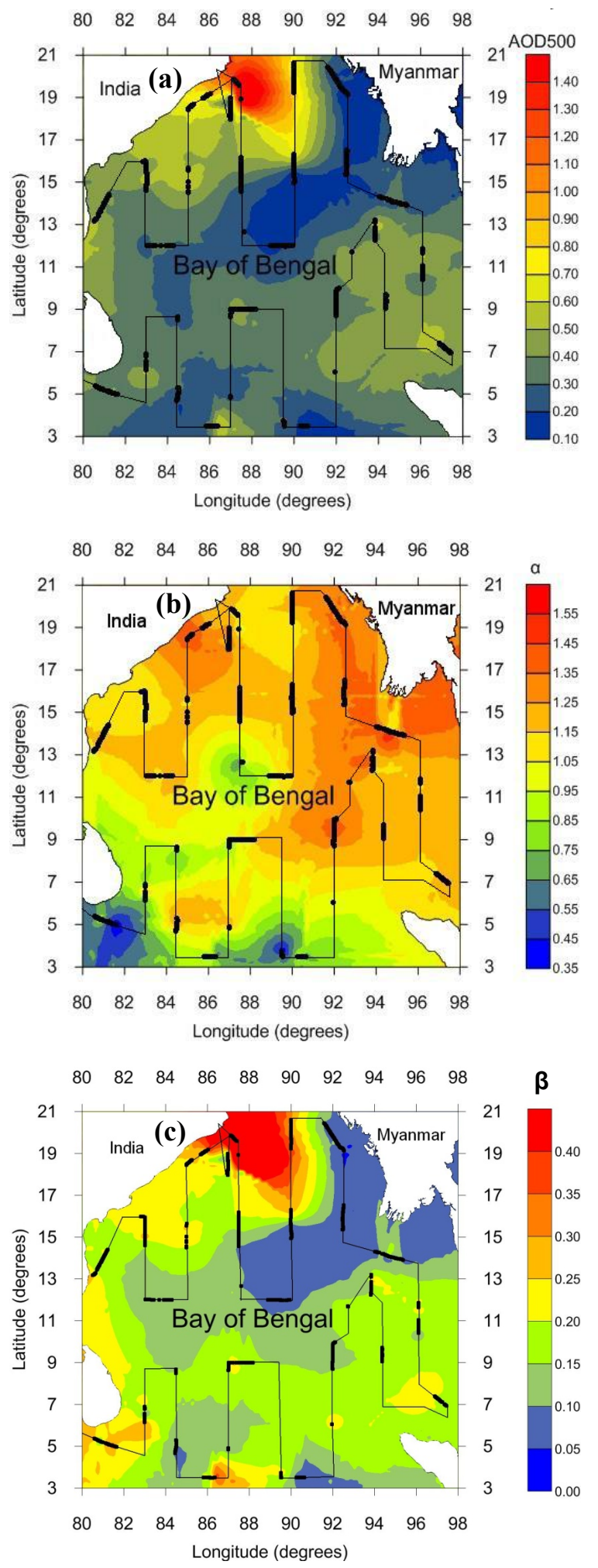

Fig. 4. Spatial distribution of (a) $\mathrm{AOD}_{500}$, (b) Angstrom wavelength exponent $\left(\alpha_{380-870}\right)$ and turbidity coefficient $(\beta)$ obtained by MICROTOPS-II over BoB during W-ICARB. The line shows the ship's movement and the dark points the sun photometer measurements. 

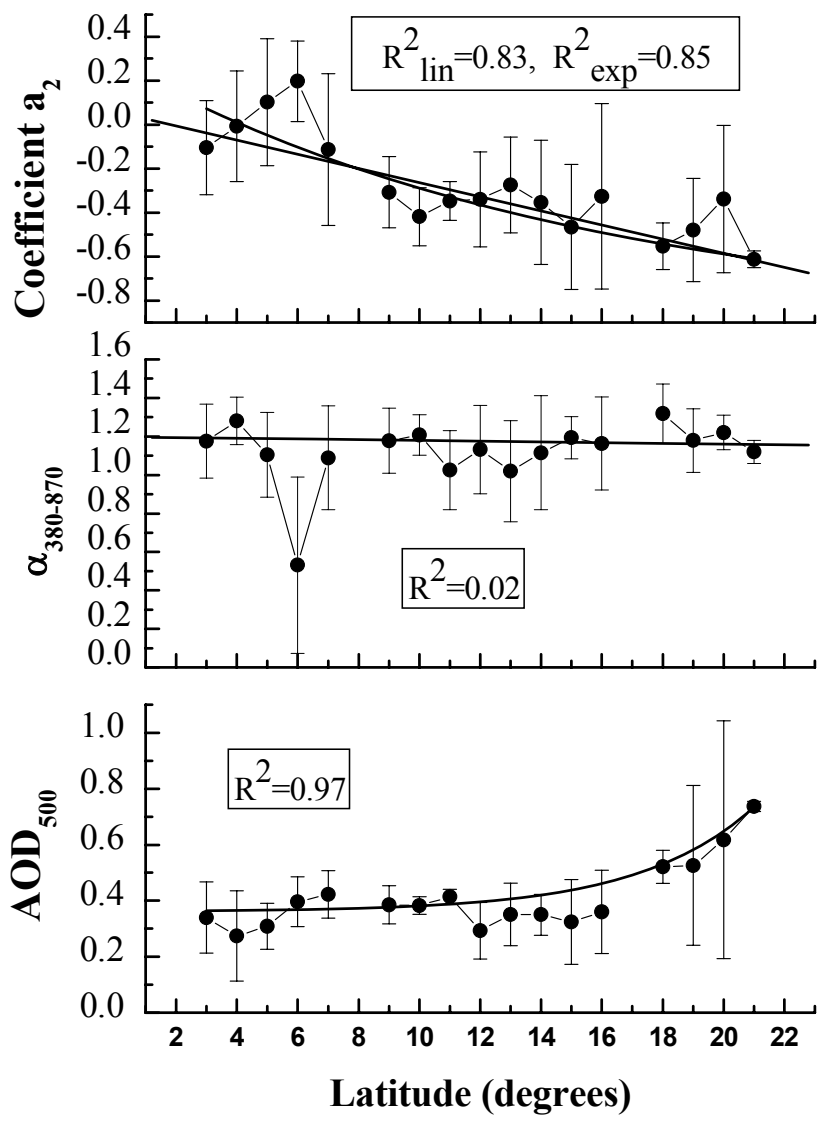

Fig. 5. Mean latitudinal variation of $\mathrm{AOD}_{500}, \alpha_{380-870}$ and coefficient $a_{2}$ over BoB during W-ICARB. The linear and exponential fits shown in the graph are: $\left[\mathrm{AOD}_{500}=0.36+\right.$ $\left.0.001 \exp ^{\wedge}(x / 3.79)\right],\left[\alpha_{380-870}=-0.002 x+1.19\right],\left[a_{2}=-0.03 x+\right.$ $0.06],\left[a_{2}=-0.91 x+1.19 \exp ^{\wedge}(x / 15.34)\right]$, where $x$ is the latitude. The $R^{2}$ values of the fits are shown in each graph.

the strict criteria applied in Kaskaoutis et al. (2011) about avoiding cloud contamination in the sun photometric measurements, the morning hours of 2 January that are used in the present study are not considered as cloud contaminated, but as high turbid.

The Ångström wavelength exponent $(\alpha)$ and turbidity coefficient $(\beta)$ were estimated in the wavelength band 380 $870 \mathrm{~nm}$ using the least squares method. The high values of $\alpha(>1.1)$ along the east Indian coast, northern and eastern $\mathrm{BoB}$ indicate relative abundance of fine and accumulationmode aerosols. The central and southern BoB showed lower $\alpha$ values (below 0.7 ), suggesting dominance of coarse-mode particles. These particles could be associated with additional production of sea-spray aerosols due to stronger winds over this area (Figs. 2, 3) affecting the concentrations of supermicron particles (Sinha et al., 2011a) at the sea surface. However, no significant correlation between columnar parameters ( $\alpha$ or AOD) and sea-surface WS was found, since there is possibility for elevated aerosol layers of continen- tal origin (Moorthy et al., 2010). The mean $\alpha_{380-870}$ was found to be $1.14 \pm 0.24$, slightly lower but with larger variation from the value $1.21 \pm 0.11$ found over $\mathrm{BoB}$, and larger than that $(0.90 \pm 0.18)$ reported over AS during ICARB-06 (Kalapureddy and Devara, 2008). This indicates that in both seasons, BoB is affected more by anthropogenic emissions from continental India and Southeast Asia than the AS. A significant finding revealed from the spatial distribution of $\alpha$ is an eastward increase for latitudes between $8^{\circ} \mathrm{N}$ and $15^{\circ} \mathrm{N}$, which was not established in the ICARB-06 campaign, since the far eastern $\mathrm{BoB}$ remained unexplored. The spatial distribution of $\beta$ seems to follow that of $\mathrm{AOD}_{500}$, since their between correlation is associated with $89 \%$ of the variance. Thus, low $(<0.15)$ values are observed near the Myanmar coast and in central $\mathrm{BoB}$ and higher in northern $(0.4<)$ and western $(0.2-0.3) \mathrm{BoB}$. The $\beta$ values are larger near coastal India than in the far eastern BoB, although these regions present similar $\mathrm{AOD}_{550}$. This indicates a stronger influence of mixed aerosols, having a larger coarse fraction over coastal India, while over eastern BoB the aerosols are of fine mode (Kaskaoutis et al., 2011). During the campaign, $\beta$ was found to be $0.17 \pm 0.09$, larger than that $(0.14 \pm 0.08)$ reported during ICARB-06 (Kalapureddy and Devara, 2008).

The results of numerous campaigns suggested that both AOD and $\alpha$ values are higher over BoB compared to those over AS and NIO, having also a more absorbing nature (e.g. Satheesh et al., 2001; Moorthy et al., 2009). A direct comparison between aerosol characteristics measured over BoB during W-ICARB and those of previous cruise campaigns is included in Moorthy et al. (2010). The large values of AOD and $\alpha$ over BoB differentiates this marine environment from an open oceanic one due to intense anthropogenic outflows, as major industries are located along the coastal region of BoB at Chennai, Kolkata, Visakhapatnam, etc., which includes cement factories, coal based thermal power plants, steel plants, etc. W-ICARB, being the most extended cruise campaign over the region in winter season, highlights a pronounced continental influence not only over northern $\mathrm{BoB}$, but also over its southern parts as has already been shown in pre-monsoon (Nair et al., 2010).

\subsection{Latitudinal dependence of aerosol properties}

Even though the oceanic environment is less heterogeneous compared to land, several studies have shown large aerosol heterogeneities over oceanic regions, even over reasonably small spatial scale (e.g. Kaskaoutis et al., 2010). Atmospheric dynamics and thermodynamics as well as long-range transport play a vital role on aerosol loading and its variations over BoB (e.g. Moorthy et al., 2009). In this respect, Fig. 5 shows the latitudinal variation of $\mathrm{AOD}_{500}, \alpha_{380-870}$, and coefficient $a_{2}$, which indicates the curvature in the $\ln \mathrm{AOD}$ vs. $\ln \lambda$ plot $\left[\ln \mathrm{AOD}=a_{2}(\ln \lambda)^{2}+a_{1} \ln \lambda+a_{0}\right]$. The coefficient $a_{2}$ can be used along with $\alpha$ for the discrimination of different aerosol types, while positive values of it correspond 
to size distribution dominated by coarse-mode particles and vice versa (Kaskaoutis et al., 2010, 2011). The latitudinal step is defined to 1 degree, while the vertical bars provide the standard deviation of the mean value due to longitudinal variation of each parameter. The $\mathrm{AOD}_{500}$ increases steadily with latitude for areas northern than $\sim 12^{\circ} \mathrm{N}$ associated with increasing in standard deviation. This latitudinal variation can be accurately fitted $\left(R^{2}=0.97\right)$ by an exponential growth function of the form $y(x)=x_{o} \exp \left(x / x_{D}\right)+B$. In this form, $x$ is the latitude (in degrees), $x_{o}$ is the latitude independent component, and $x_{D}$ is the scaling distance (in degrees) corresponding to an e-fold change in $y$ (AOD) in degrees of latitude. The scaling distance is commonly used for such studies in order to reveal how steep the variation is in aerosol properties as a function of latitude or of the distance from the coast (Ramachandran, 2004). The results show a scaling distance of $3.8^{\circ} \pm 1.7^{\circ}$, which is much lower than that $\left(10.6^{\circ}\right)$ found by Moorthy et al. (2010) over the same area during W-ICARB. The difference is mainly attributed to the use of the very high morning AOD values on 2 January 2009 in the present study, which leads to higher AODs in the northern latitudes, as well as to the use of the AOD value for $21^{\circ} \mathrm{N}$, which is not used by Moorthy et al. (2010). Excluding these two values, the scaling distance was found to be $8.9^{\circ} \pm 1.3^{\circ}$, which is much closer to the value reported by Moorthy et al. (2010). In great similarity with the present results, the long-term (2000-2009) MODIS AOD 550 latitudinal variation over $\mathrm{BoB}$ (for latitudes greater than $8^{\circ} \mathrm{N}$ ) in January showed an exponential growth with scaling distance of $3.4^{\circ} \pm 1.2^{\circ}$ (not shown). In contrast, $\alpha_{380-870}$ does not show any remarkable latitudinal variation during W-ICARB except of the lesser values for $<8^{\circ}$. Previous observations during ICARB-06 (e.g. Kedia and Ramachandran, 2008) have shown a strong south-to-north gradient of increasing AOD and $\alpha$ over BoB. The latitudinal variation of $\alpha$ from Fig. 5 seems to be somewhat different to that observed in the spatial distribution of this parameter (Fig. 4b), This inconsistency is attributed to the limited $\alpha_{380-870}$ values for latitudes below $8^{\circ} \mathrm{N}$. For example, at $6^{\circ} \mathrm{N}$ the availability of data is limited over the southwestern BoB (note the black dots in Fig. 4), thus leading to smaller $\alpha_{380-870}$ than that at $4^{\circ}$ and $5^{\circ}$. The curvature $\left(a_{2}\right)$ exhibits a continuously decreasing trend towards northern $\mathrm{BoB}$, which is an indication of finemode aerosol dominance. The scaling distance was found to be $15.3^{\circ}$, with the exponential decay function presenting high accuracy (0.86). The $a_{2}$ values in southern BoB and NIO are characteristics of super-micron particle size (positive $a_{2}$ ), while those for latitudes larger than $8^{\circ} \mathrm{N}$ for accumulation and fine-mode aerosols. Similarly to our results, Moorthy et al. (2010) found that the latitudinal variation of the accumulation mass concentration and accumulation mass fraction can be simulated by an exponential growth function with high accuracy $\left(R^{2}=0.96\right.$ and 0.92 , respectively) and scaling distance of $\sim 18^{\circ}$. These results show a consistency between columnar and MABL aerosol characteristics.
Besides the clearly defined latitudinal gradient, a rather variable longitudinal one was found (not presented) depending strongly on the latitudinal belt. Thus, over northern BoB $\left(>19^{\circ} \mathrm{N}\right)$ there is a strong longitudinal gradient with decreasing values of $\mathrm{AOD}_{500}$ and increasing values of $a$ from west to east (see also Fig. 4). Between $12^{\circ} \mathrm{N}$ and $17^{\circ} \mathrm{N}$, the $\mathrm{AOD}_{500}$ and $\alpha$ present larger values near the Indian coast, which are continuously decreasing in the central part and increasing again in the far east $\mathrm{BoB}\left(>92^{\circ} \mathrm{E}\right)$, while in southern $\mathrm{BoB}$ and NIO $\left(<8^{\circ} \mathrm{N}\right)$ both $\mathrm{AOD}_{500}$ and $\alpha$ exhibit insignificant longitudinal variation. A previous study (Ramachandran, 2004) showed that the spectral AOD presented a steep longitudinal gradient, as the ship was moving from the Indian coast towards the pristine oceanic region, thus highlighting the reduced anthropogenic influence in central BoB.

\subsection{Aerosol and pollution transport over BoB}

In order to identify the sources of high aerosol loading over the northern BoB, Terra/Aqua MODIS true color images are shown on 7 January 2009, when the ship was crossing the north BoB (Fig. 6). An intense hazy-aerosol layer over IGP and Bangladesh is clearly shown by satellite images, indicating a strong continental outflow towards the marine environment. During W-ICARB such aerosol layers are transported towards downwind direction over northern $\mathrm{BoB}$, resulting in dramatic increase in $\mathrm{AOD}_{500}$ and $\beta$ values on 31 December $2008(0.68 \pm 0.07,0.25 \pm 0.03), 2$ January $(1.53 \pm 0.17$, $0.67 \pm 0.09)$, and 7 January $2009(0.76 \pm 0.06,0.31 \pm 0.03)$ and limitation of visibility.

Such dense fog and hazy conditions are very common over IGP during winter (e.g. Singh et al., 2004; Ramachandran et al., 2006; Gautam et al., 2007; Das et al., 2008), which traps the aerosols and pollutants near the ground. The large amount of water-soluble aerosols over IGP provides the necessary condensation nuclei for the formation of fog near the ground, especially when the RH is high (Badarinath et al., 2007b). These thick aerosol layers have attracted scientific interest in recent years, described as "Atmospheric Brownish Clouds, ABC" (Ramanathan et al., 2005; Lawrence and Lelieveld, 2010) that are comprised mainly of Black Carbon (BC), sulphate, ammonium, and nitrate. Burning of biofuels, such as wood, agricultural waste, and dried animal manure in cooking stoves, is the largest source of $\mathrm{BC}$ emissions in India, contributing $42 \%$ of the total (Venkataraman et al., 2005). The ABC can be even $3-\mathrm{km}$ thick and can be transported several kilometers downwind, affecting south India and the adjoining oceanic regions (Ramanathan et al., 2005). Furthermore, they absorb the solar radiation heating the atmosphere, thus causing a temperature anomaly over northern India (Gautam et al., 2010) able to cause the melting of the Himalayan glaciers (Prasad et al., 2009; Menon et al., 2010).

Although MODIS sensors can clearly detect the aerosol loading over IGP and BoB, its thickness and vertical extend cannot be monitored. For this reason, lidar systems on 



Fig. 6. True Color Composite images of Terra/Aqua MODIS on 7 January 2009 over the northern BoB.

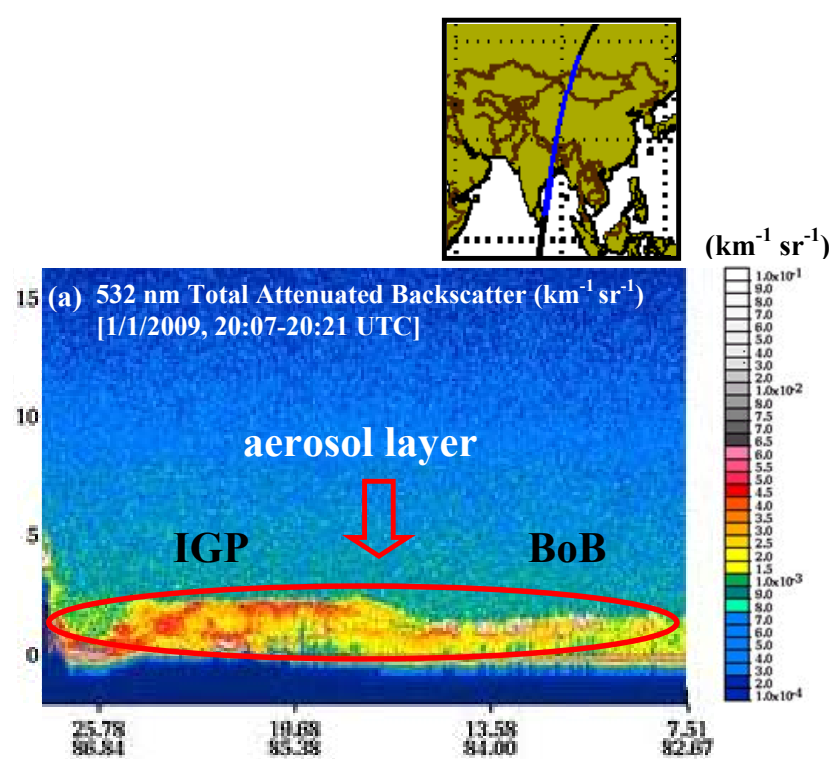

board satellites (such as CALIPSO) have been increasingly available in the last years in order to identify the vertical extent of aerosols. A typical example of the vertical distribution of the aerosol plume over BoB on 1 January 2009 is shown in Fig. 7a, b for total attenuated backscatter coefficient and depolarization ratio at $532 \mathrm{~nm}$, respectively. The nighttime CALIPSO overpass moving southwards covers Tibetan Plateau, eastern IGP, and northwestern BoB. On that day the ship was crossing the northwestern $\mathrm{BoB}\left(18.3^{\circ} \mathrm{N}\right.$, $86.9^{\circ} \mathrm{E}$ ) while the daily mean $\mathrm{AOD}_{550}$ and $\alpha_{380-870}$ values were $0.49 \pm 0.05$ and $1.28 \pm 0.09$, respectively.

The thick aerosol layer, extending from surface up to $\sim 3$ $\mathrm{km}$ altitude, is quite detectable by CALIPSO, covering IGP and northwestern part of BoB; this aerosol layer is developed just below the foothills of the Himalayas, into the topographic low basin of Ganges river. The backscatter profile is characterized by large attenuation values $(0.002$ $0.005 \mathrm{~km}^{-1} \mathrm{sr}^{-1}$ ) within the aerosol layer. A significant finding revealed from CALIPSO observations is the slightly larger vertical extend of the aerosol layer over IGP, whose thickness is reduced over $\mathrm{BoB}(<\sim 2 \mathrm{~km})$. The larger height of mixed layer over land compared to the shallower MABL seems to play a vital role in the vertical extend of aerosols as well as the gravitational settling of the particles for large distances of their source regions. Thus, the aerosol layer shows a continuous attenuation towards south $\mathrm{BoB}\left(7^{\circ}-8^{\circ} \mathrm{N}, 82^{\circ}-\right.$ $83^{\circ} \mathrm{E}$ ), consistent with the results of Moorthy et al. (2010). The depolarization ratio is defined as the ratio of the perpendicular and parallel components of the attenuated backscatter signal (Liu et al., 2008), and is a good proxy to distinguish between spherical (e.g. sulfate) and non-spherical (e.g. cloud droplets, dust) aerosols; higher values correspond to non-spherical particles. The depolarization ratio values are below 0.1 within the thick aerosol layer both over IGP and $\mathrm{BoB}$, indicating a homogeneous layer of pollution and finemode aerosols.

Except for the CALIPSO observations on 1 January, the CALIPSO extinction coefficient at $532 \mathrm{~nm}$ showed much larger values $\left(\sim 0.17-0.22 \mathrm{~km} \mathrm{sr}^{-1}\right)$ within the MABL in the 

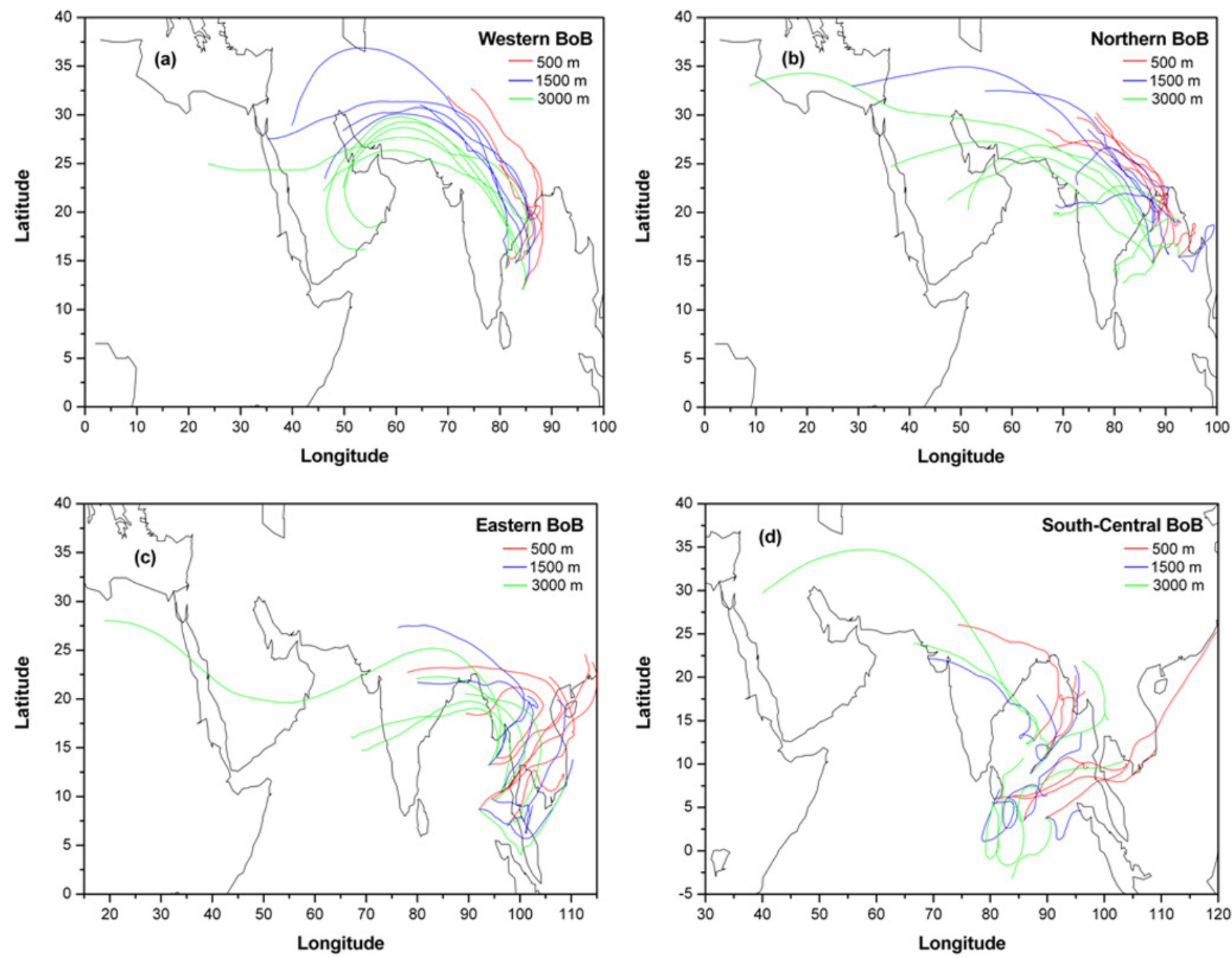

Fig. 8. Five days back trajectories by means of HYSPLIT model at $500 \mathrm{~m}, 1500 \mathrm{~m}$, and $3000 \mathrm{~m}$, for all the days of the W-ICARB campaign. The cruise track period has been divided into 4 parts depending on the ship location (west $\mathrm{BoB}$, north $\mathrm{BoB}$, east $\mathrm{BoB}$ and south-central $\mathrm{BoB}$ ).

north and west $\mathrm{BoB}$ than those $\left(0.05-0.1 \mathrm{~km} \mathrm{sr}^{-1}\right)$ observed over the other BoB sub-regions (Moorthy et al., 2010). Moreover, distinct elevated aerosol layers were noticed over west and north BoB at altitudes between $0.5 \mathrm{~km}$ and $2 \mathrm{~km}$, which are consisted with the aircraft-based observations over the east coast of India (Babu et al., 2008; Satheesh et al., 2009). This indicates that the outflow of aerosols over the northern parts of $\mathrm{BoB}$ is confined both within the MABL and in the middle troposphere affecting the atmospheric heating rates and the aerosol forcing over the area (Moorthy et al., 2009). The elevated aerosol layers observed in variable intensity over the whole $\mathrm{BoB}$ contribute to the vertical heterogeneity in aerosol load and characteristics over the region (Sinha et al., 2011b).

\subsection{Influence of air-mass trajectories}

In order to understand the various aerosol sources, 5-day isentropic air mass back-trajectory analysis was used by means of HYSPLIT model (Draxler and Rolph, 2003) at $500 \mathrm{~m}, 1500 \mathrm{~m}$, and $3000 \mathrm{~m}$ a.m.s.l. For better analysis, the BoB has been divided into the 4 sub-regions (a) west, (b) north, (c) east, and (d) south-central (Fig. 8a-d).

In general, the back-trajectories can be divided into four main sectors: (i) northwest, for trajectories coming from continental India and IGP; (ii), east, for air masses originating from Southeast Asia; (iii) south, for air masses transported from the tropical Indian Ocean; and (iv) west, for air masses coming from arid regions in the Middle East and then crossing continental India before reaching BoB. Different types of aerosols are expected for each individual sector. Thus, for the northwest and east sectors the air masses 


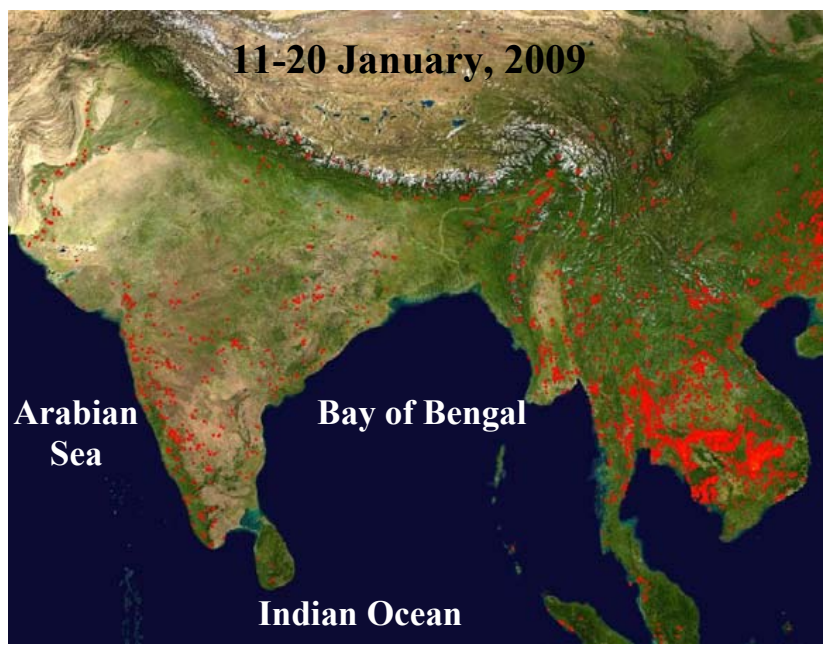

Fig. 9. MODIS-derived active fire locations over South Asia during 11-20 January 2009, when the ship was crossing the eastern BoB.

carry mainly anthropogenic aerosols from densely populated regions. Large consumption of fossil fuels and biomass burning are the major sources of the anthropogenic aerosols produced in these regions (Reddy and Venkataraman, 2002). The tropical air masses carry marine coarse-mode aerosols, while the west air masses contain dust particles mixed with anthropogenic ones.

During the first days of the cruise (27-31 December 2008), the air masses are from western/northwestern directions (Fig. 8a) originating from desert regions in Iran, Pakistan, and northwestern India (mainly at $3000 \mathrm{~m}$ ). These air masses are crossing continental India before reaching over BoB. Despite the anthropogenic-aerosol transport, they can also carry (mainly above $2 \mathrm{~km}$ ) dust from the arid landscapes in the west under favorable atmospheric conditions. However, the dust outbreaks are rather rare in winter, affecting more the northern AS and not so much the BoB (Badarinath et al., 2010). As the altitude decreases the air masses originate from IGP carrying anthropogenic aerosols and pollutants over the coastal $\mathrm{BoB}$, resulting in higher abundance of sub-micron aerosols mixed with natural ones under the development of the dense fog conditions.

In the north BoB (Fig. 8b), the air masses seem to have a more complicated pattern, with the western and northwestern sector dominate, providing conduits for transport of continental aerosols. The lower air masses are originated from IGP, carrying significant amount of aerosols over the region, which accounts for the observed high AODs (Fig. 4a) and accumulation-mode dominance (Fig. 4b). The northeastern $\mathrm{BoB}$ exhibits the lowest $\mathrm{AOD}_{500}$ (Fig. 4a) and the highest $\alpha$ (Fig. 4b). When the ship was crossing this region, the air masses indicated mainly from costal India $(3000 \mathrm{~m})$ and coastal Myanmar $(500 \mathrm{~m}, 1500 \mathrm{~m})$ and devoid of significant continental advection, being mainly oceanic in nature. More- over, since the coastal eastern India shows large $\alpha$ values, this kind of aerosol transport is responsible for the $\alpha>1.4$ over the northeastern BoB.

When the ship was crossing the eastern BoB, the air masses at all levels (except very few) originated from Southeast Asia (Fig. 8c), carrying anthropogenic aerosols over the region, contributing significantly to the enhanced AOD and $\alpha$ values. The role of such transport in increasing the $\mathrm{AOD}$ at shorter wavelengths and $\mathrm{BC}$ mass concentration in the eastern $\mathrm{BoB}$ has also been reported by long-term observations (Moorthy and Babu, 2006). Furthermore, Moorthy et al. (2003) reported larger AOD and $\alpha$ values at Port Blair (eastern BoB) when associated with air masses coming from Southeast Asia. However, the eastern BoB presents lower AODs compared to the northern and western parts, since Southeast Asia does not contain such large amounts of aerosols as IGP.

In central and southern BoB (Fig. 8d), the air masses are mainly from eastern directions, originating from coastal Southeast Asia and spend a large time over the marine environment. This justifies the lower AOD $(\sim 0.2)$ and the moderate values of $\alpha(0.8-1.0)$ over the region as a result of a rather mixed aerosol type consisting of coarse (sea salt) and fine (anthropogenic) aerosols. The dominance of the oceanic air masses associated with the larger WS in the south BoB are the indicators of producing coarse-mode sea-salt aerosols over this region. Air masses of marine origin were also found during ICARB-06 when the ship was cruising the south $\mathrm{BoB}$ (Nair et al., 2009), resulting in lower AOD and $\alpha$ values.

In order to further explain the large AOD and $\alpha$ values over far eastern $\mathrm{BoB}$, daily datasets of MODIS fire counts were analyzed for active forest fire locations, which are significant sources of aerosols over South Asia (e.g. Venkataraman et al., 2006). Figure 9 shows the active fires as detected from MODIS fire response system (http://rapidfire.sci.gsfc. nasa.gov/firemaps/) over Southeast Asia during the period 11-20 January 2009 when the ship was crossing the eastern part of the BoB. The open fires are mainly detected in Southeastern Asia and in some locations in central and western India, whereas very few exist over IGP. It was found that the fire spots in Southeast Asia present a slight increasing trend towards the end of the cruise period. Thus, when the ship was crossing the eastern BoB (10-18 January), the easterlies (Figs. 2, 8c) transported biomass-burning aerosols over this area. However, MODIS images did not show any severe fires in Southeast Asia able to cause a dramatic increase in AOD values on a specific day. Despite this, the fires seem to significantly affect the accumulation-mode abundance over eastern BoB and, more specifically, near coastal regions as indicated by the large $(>1.4) \alpha$ values. This is the reason for the clear dominance of the fine-mode aerosols (anthropogenic-pollution type) found over BoB by Kaskaoutis et al. (2011). Far away from the fire locations, in central and south BoB where the air masses remained from eastern directions (Fig. 8d), there is significant reduction of 

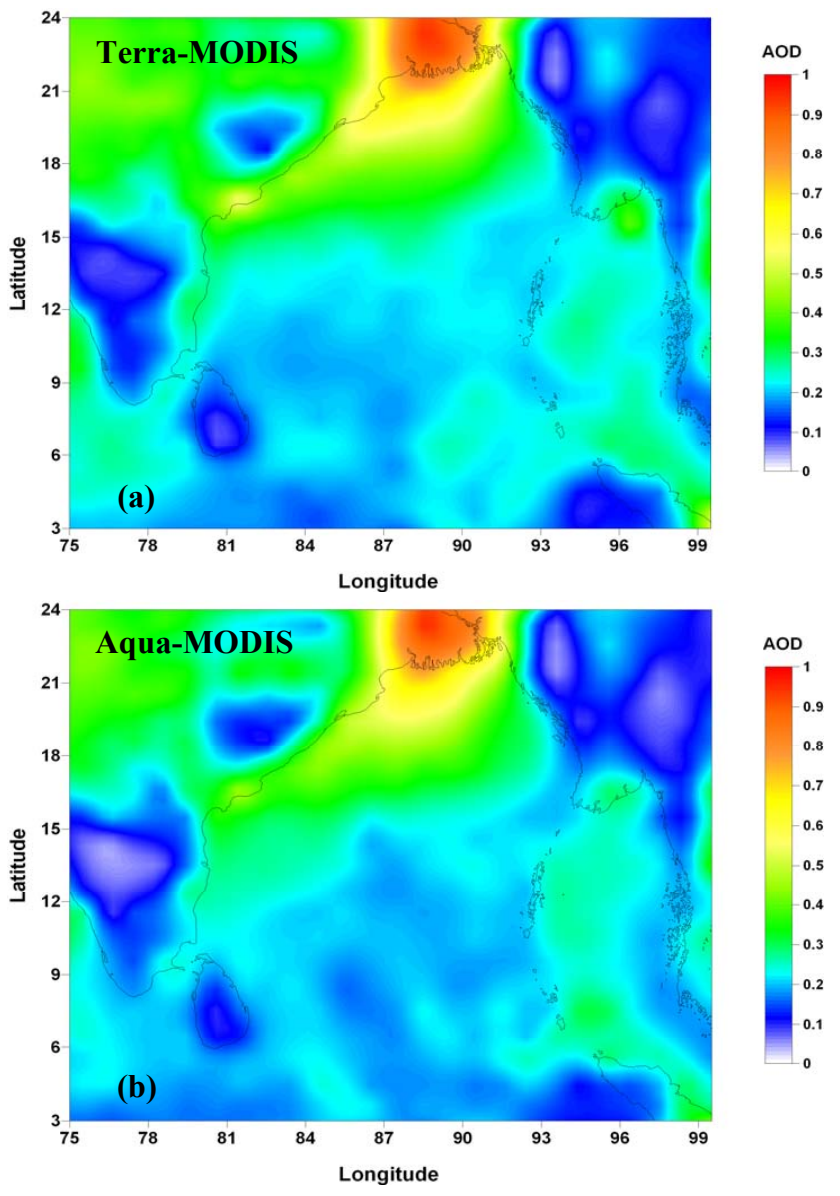

Fig. 10. Mean spatial distribution of Terra (a) and Aqua (b) MODIS AOD $_{550}$ over BoB during W-ICARB (27 December 2008-30 January 2009). The MODIS data correspond to collection 5 (C005) Level $3\left(1^{\circ} \times 1^{\circ}\right)$.

the biomass-burning influence due to subsidence and dispersion of the aerosols.

\subsection{Comparison between MICROTOPS-II and MODIS}

The $\mathrm{AOD}_{500}$ and $\alpha_{380-870}$ spatial distributions (Fig. 4a, b) were prepared using the whole set of measurements onboard a moving platform; thus, we cannot have the spatial distribution of the aerosol optical properties over the entire BoB at the same time. Therefore, one can believe that these graphs consist of a degree of arbitrariness and the presented figures cannot be representative for the whole duration of the $\mathrm{W}$ ICARB cruise, since the measurements can be changed at a specific location depending on time and prevailing meteorology. In this respect, Fig. 10a-b shows the spatial distribution of Terra/Aqua MODIS mean $\mathrm{AOD}_{550}$ over BoB during W-ICARB. The comparison of the Figs. $4 \mathrm{a}$ and $10 \mathrm{a}, \mathrm{b}$ reveals a general consistency between the $\mathrm{AOD}_{500}$ spatial distributions obtained from onboard measurements and those from satellite observations; however, such comparisons must
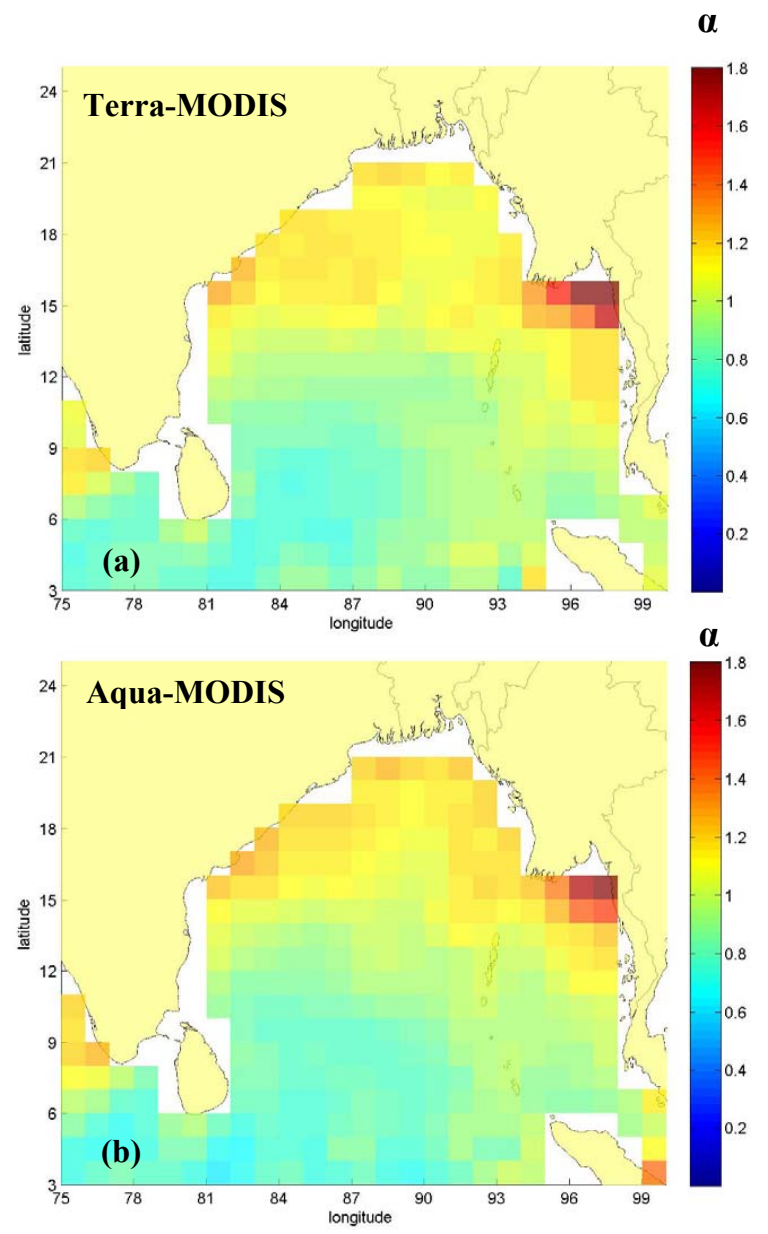

Fig. 11. Same as in Fig. 10, but for the Angstrom exponent $\alpha_{550-865}$.

be considered qualitative and not quantitative. The mean MODIS AOD 550 shows enhanced values over northern $\mathrm{BoB}$, along the east Indian coast, and in the far east BoB in close agreement with the ship-borne measurements. Note also the similarity between satellite and ship-borne observations regarding the lower $\mathrm{AOD}_{550}$ in central-south $\mathrm{BoB}$ and close to Myanmar coast. Furthermore, the daily Terra and Aqua MODIS AOD 550 values are similar with a correlation coefficient of 0.9 and mean values of $0.35 \pm 0.12$ for Terra and $0.32 \pm 0.12$ for Aqua.

Similarly, Fig. 11a, b shows the mean spatial distribution of Terra/Aqua MODIS $\alpha_{550-865}$ over BoB using the ocean algorithm. Higher $\alpha_{550-865}$ values are observed over north, west, and east BoB, but lower (in general $<0.7$ ) values in central and southern parts of BoB and NIO, consistent with the cruise observations (Fig. 4b). The two MODIS sensors reveal a similar spatial distribution and mean value of $0.99 \pm 0.18$ for Terra and $0.98 \pm 0.19$ for Aqua; their between correlation is associated with $75 \%$ of the variance, lower than that found for $\mathrm{AOD}_{550}$. 
(a)
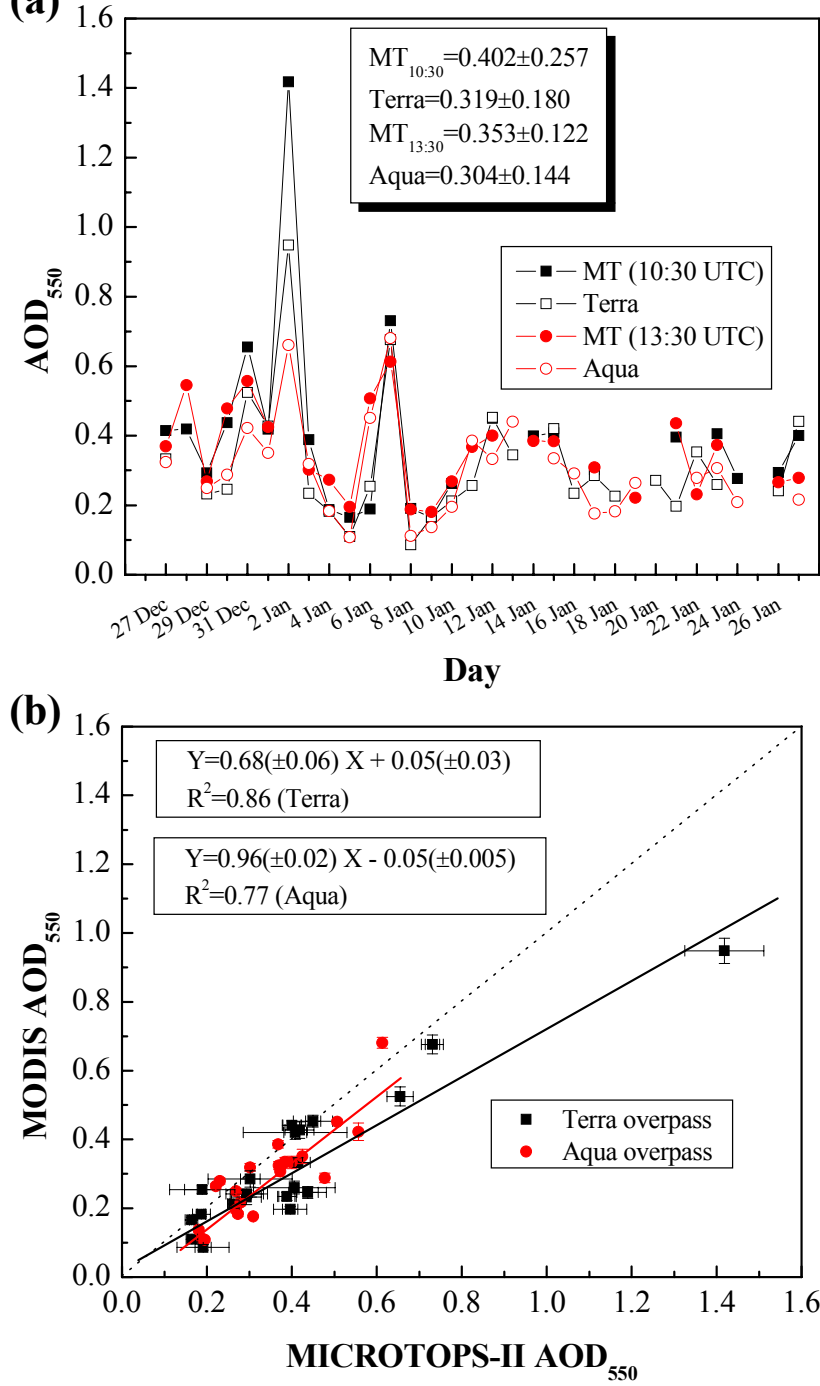

Fig. 12. Day-to-day variation of the $\mathrm{AOD}_{550}$ obtained from Terra/Aqua MODIS and MICROTOPS-II, MT (a), and their between correlation (b). The MODIS data correspond to areaaveraged values (Level 3) along the daytime ship movement, while the MICROTOPS-II AOD $_{550}$ are the temporal-means within $\pm 30 \mathrm{~min}$ of the Terra/Aqua overpass.

Despite the good qualitative correlation between shipborne and satellite mean spatial distributions, a more detailed analysis is now given regarding the consistency between MT and MODIS over BoB. In this respect, MODIS level 3 (C005) data covering the daytime movement of the ship are correlated with MT data averaged over a time interval of $\pm 30 \mathrm{~min}$ around the Terra and Aqua overpass. As the $550 \mathrm{~nm}$ channel was not available in MT, the AOD for this wavelength was estimated using $\alpha_{380-870}$. The day-to-day variation of MT and Terra/Aqua MODIS $\mathrm{AOD}_{550}$ as well as their between correlations are shown in Fig. 12a, b, respectively. Some lack of data on certain days during the end of the cruise is attributed to cloud formation over the ship location at the time of Terra and/or Aqua overpass. In general, ship-borne and satellite observations reveal a similar temporal pattern during the whole duration of the cruise campaign. The peaks in MT AOD 550 (31 December 2008, 2 January and 7 January 2009) are well represented by MODIS despite the larger differences in the values. The MT AOD 550 around the Terra overpass is higher $(0.40 \pm 0.26)$ compared to that of Aqua overpass $(0.35 \pm 0.12)$. The relative large difference is attributed to the unavailability of data on the same days and ship locations, mainly due to formation of clouds, i.e. exclusion of the high $\mathrm{AOD}_{550}$ value at 10:30 on $2 \mathrm{Jan}$ uary (not available at 13:30) will reduce the morning MT $\mathrm{AOD}_{550}$ to 0.36. The correlation between the MT AOD 550 values in a time interval of $\sim 3 \mathrm{~h}$ is $R^{2}=0.6$. It is worth noting that the 10:30 MT $\mathrm{AOD}_{550}$ is larger than the respective one at 13:30 when the ship was cruising western and northern $\mathrm{BoB}$, while in eastern and southern $\mathrm{BoB}$ this is not the case. This indicates that in coastal waters the AOD diurnal variation follows the continental one, which is comprised by higher values at morning hours reducing due to aerosol dilution at local noon (e.g. Badarinath et al., 2007a). The scatter plot between Terra/Aqua MODIS and MT AOD 550 (Fig. 12b) suggests a good correlation $\left(R^{2}=0.86\right.$ and 0.77 , for Terra and Aqua, respectively). The vertical and horizontal bars correspond to the standard deviations revealed by the spatial averaged (MODIS) and the temporal averaged (MT) values. It is observed that the ship-borne and satellite AODs are in close agreement for lower values, while for large $\mathrm{AOD}_{550}$ the inconsistency increases. The observed correlations are similar to those reported over BoB during ICARB-06 (Aloysius et al., 2008) and from previous campaigns (e.g. Vinoj et al., 2004). In general, MODIS underestimates MT AODs, with larger differences $(0.2-0.4)$ over northern BoB and very low $(<0.07)$ differences over central and south BoB. Similarly, Kedia and Ramachandran (2008) found higher MT AODs compared to those from MODIS over BoB during ICARB-06.

Similar analysis is performed for the $\alpha$ values. For consistency with the MODIS retrievals $\left(\alpha_{550-865}\right)$, the MT $\alpha$ values were calculated in the band $500-870 \mathrm{~nm}$. We did not use the region $550-870 \mathrm{~nm}$ in order to avoid additional uncertainties in $\alpha$ revealed from the calculated $\mathrm{AOD}_{550}$. The day-to-day variation of the MT and MODIS $\alpha$ is shown in Fig. 13a. Opposite to $\mathrm{AOD}_{550}$, MT and MODIS sensors present significant differences in the temporal variation of $\alpha$. However, all data agree to a general decrease in $\alpha$ values on the last days of the cruise campaign as well as to the low value on 4 January. The mean MT $\alpha$ values are larger than those of Terra and Aqua, although their between differences are low $(\sim 10$ $11 \%)$. Figure 13a also reveals a systematic MODIS underestimation during the second half of the cruise over southeast and south BoB. This is probably attributed to the fact that the MODIS algorithms assume a marine aerosol model, with reduced $\alpha$ values, for the aerosol retrievals over this area, 
while advection from anthropogenic aerosols can be important. The correlation between the MT $\alpha$ values at 10:30 and $13: 30$ is similar to that for $\operatorname{AOD}_{550}\left(R^{2}=0.61\right)$, while between Terra and Aqua is very low $\left(R^{2}=0.2\right)$, indicating the increased satellite uncertainties in retrieving parameters related to aerosol size (Levy et al., 2007). As expected, the correlation between MT and MODIS $\alpha$ values shows larger scatter (Fig. 13b) compared to that for $\mathrm{AOD}_{550}\left(R^{2}=0.38\right.$ and 0.33 for Terra and Aqua, respectively), while except for a few cases, MODIS systematically underestimates the MT $\alpha$ values.

\section{Conclusions}

Ship-borne spectral aerosol measurements using a MT sunphotometer along with Terra/Aqua MODIS observations over BoB during W-ICARB cruise campaign (27 December 2008-30 January 2009) were analyzed aiming at exploring the aerosol spatial distribution over the oceanic environment and to highlight the role of continental advection. The main findings of the study are as follows:

- Large spatial heterogeneity existed in aerosol properties related with aerosol loading and size distribution. Thus, the spatial distributions of $\mathrm{AOD}_{500}, \alpha$, and $\beta$ showed higher values near the coast and northern BoB attributed to the anthropogenic aerosol advection from continental regions. Large values of $\mathrm{AOD}_{500}(>0.7)$ occurred over northern BoB, while in central and southern BoB the $\mathrm{AOD}_{500}$ was $\sim 0.1-0.2$.

- Similarly to the AOD, the Angstrom exponent showed larger values in northern and eastern $\mathrm{BoB}(>1.2)$, while its values dropped to $\sim 0.7$ in central and southern BoB.

- During W-ICARB the majority of the air masses had a northwestern or eastern direction carrying anthropogenic aerosols and/or biomass burning enhancing AOD and its spectral dependence over the marine environment. The largest $\alpha$ values over east BoB could be explained by biomass-burning episodes in Southeast Asia, with the easterly air masses influencing the aerosol load over the region. Furthermore, the air masses influencing the west and north BoB carried significant amounts of anthropogenic aerosols and pollutants from IGP mixed with natural ones. Being downwind of these two major aerosol source regions, BoB experienced high concentrations of fine-mode aerosols from continental anthropogenic sources and/or biomass burning.

- In the winter season, fog/aerosol conditions over IGP are a very common phenomenon. Such thick fog/aerosol layers were transported over northern BoB, causing large increase in $\mathrm{AOD}_{500}$ and reaching even above 1.0 on certain days (e.g. 2 January). The (a)
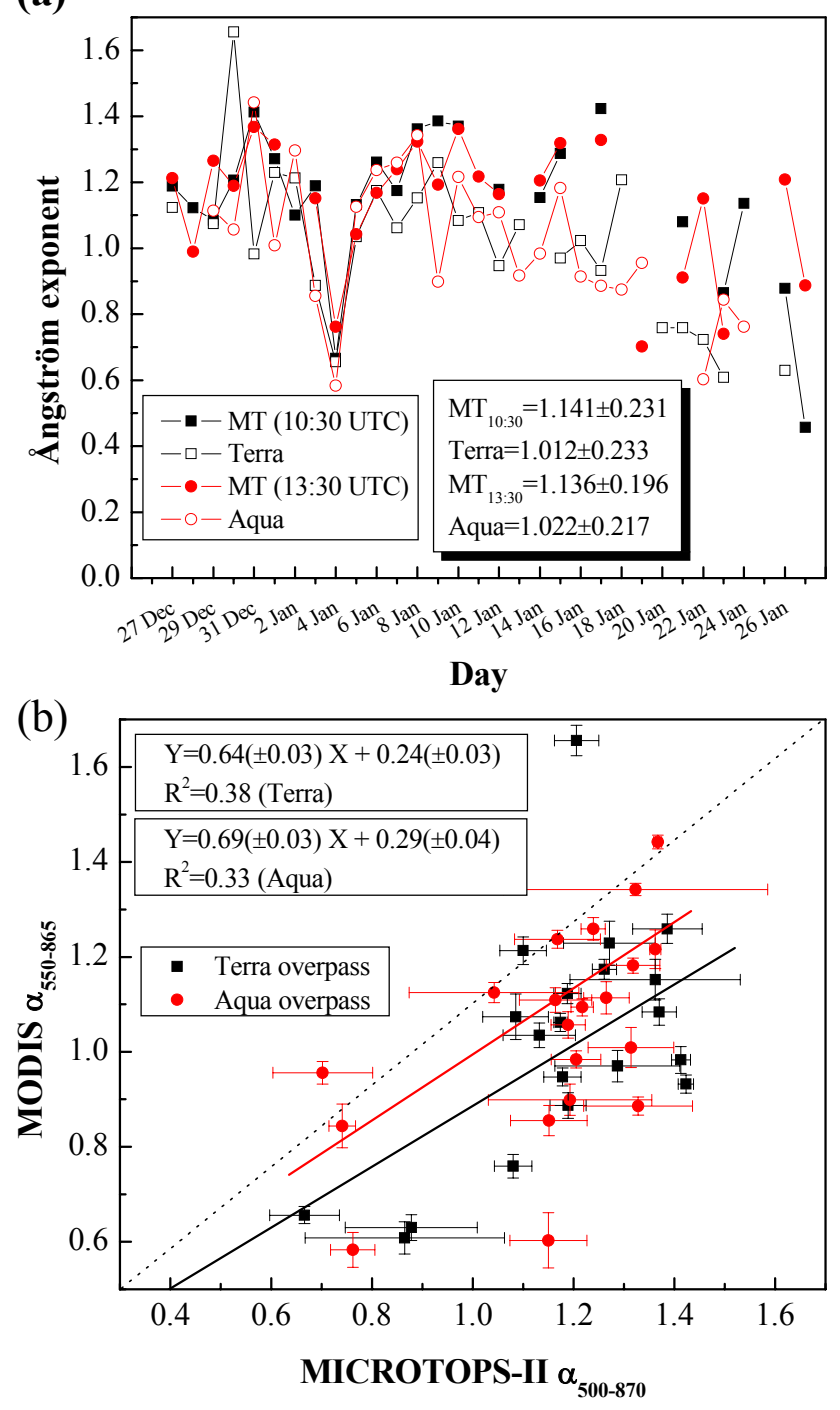

Fig. 13. Same remarks as in Fig. 12, but for the Angstrom exponent.

CALIPSO observations showed large spatial and vertical extent of such aerosol layers over BoB.

- The MT AOD550 values were in general agreement with those of Terra/Aqua MODIS $\left(R^{2}=0.86\right.$ and 0.77 , respectively), while a MODIS underestimation was found for large AODs. The respective correlations between the $\alpha$ values were not so good $\left(R^{2}=0.33-0.38\right)$.

- The close agreement both in values and spatial distributions of the AOD and $\alpha$ between the cruise measurements and satellite sensors indicated that the spatial distribution of the aerosol properties obtained from measurements at different locations and time intervals during the cruise campaign can be assumed representative during a one month period (January 2009). 
Acknowledgements. The authors are thankful to Director, NRSC and Dy. Director (RS\&GIS-AA) for necessary help at various stages and ISRO-GBP for funding support. We also thank the Department of Ocean Development for giving us the opportunity to conduct measurements on board Sagar Kanya. The authors gratefully acknowledge the NOAA Air Resources Laboratory (ARL) for the provision of the HYSPLIT transport and dispersion model and/or READY website (http://www.arl.noaa.gov/ready.php) used in this publication. Analyses and visualizations used in this study were produced with the Giovanni online data system, developed and maintained by the NASA GES DISC. We also acknowledge the MODIS mission scientists and associated NASA personnel for the production of the data used in this research effort. Finally the NCEP/NCAR scientific team is gratefully acknowledged for providing data from its website.

Topical Editor P. M. Ruti thanks two anonymous referees for their help in evaluating this paper.

\section{References}

Aloysius, M., Mohan, M., Babu, S. S., Nair, V. S., Parameswaran, K., and Moorthy, K. K.: Influence of circulation parameters on the AOD variations over Bay of Bengal during ICARB, J. Earth Syst. Sci., 117(S1), 353-360, 2008.

Babu, S. S., Satheesh, S. K., Moorthy, K. K., Dutt, C. B. S., Nair, V. S., Alappattu, D. P., and Kunhikrishnan, P. K.: Aircraft measurements of aerosol black carbon from a coastal location in the north-east part of peninsular India during ICARB, J. Earth Syst. Sci., 117, 263-271, 2008.

Badarinath, K. V. S., Kharol, S. K., Kaskaoutis, D. G., and Kambezidis, H. D.: Influence of atmospheric aerosols on solar spectral irradiance in an urban area, J. Atmos. Sol. Ter. Phys., 69, 589-599, 2007b.

Badarinath, K. V. S., Latha, K. M., Kiran Chand, T. R., Reddy, R. R., Rama Gopal, K., Reddy, L. S. S., Narasimhulu, K., and Kumar, K. R.: Black carbon aerosols and gaseous pollutants in an urban area in North India during a fog period, Atmos. Res., 85, 209-216, 2007a.

Badarinath, K. V. S., Kharol, S. K., Kaskaoutis, D. G., Sharma, A. R., Ramaswamy, V., and Kambezidis, H. D.: Long range transport of dust aerosols over Arabian Sea and Indian region - A case study using satellite data and ground-based measurements, Global Planet. Change, 72, 164-181, 2010.

Cachorro, V. E., Romero, P. M., Toledano, C., Cuevas, E., and de Frutos, A. M.: The fictitious diurnal cycle of aerosol optical depth: A new approach for "in situ" calibration and correction of AOD data series, Geophys. Res. Lett., 31, L12106, doi:10.1029/2004GL019651, 2004.

Das, S. K., Jayaraman, A., and Misra, A.: Fog-induced variations in aerosol optical and physical properties over the Indo-Gangetic Basin and impact to aerosol radiative forcing, Ann. Geophys., 26, 1345-1354, doi:10.5194/angeo-26-1345-2008, 2008.

Diner, D. J., Ackerman, T. P., Anderson, T. L., Bsenberg, J., Braverman, A. J., Charlson, R. J., Collins, W. D., Davies, R., Holben, B. N., Hostetler, C. A., Kahn, R. A., Martonchik, J. V., Menzies, R. T., Miller, M. A., Ogren, J. A., Penner, J. E., Rasch, P. J., Schwartz, S. E., Seinfeld, J. H., Stephens, G. L., Torres, O., Travis, L. D., Wielicki, B. A., and Yu, B.: Progressive Aerosol Retrievel and Assimilation Global Observing Network
(PARAGON): An integrated approach for characterizing aerosol climatic and environmental interactions, B. Am. Meteorol. Soc., 85(10), 1491-1501, 2004.

Draxler, R. R. and Rolph, G. D.: HYSPLIT (Hybrid single-particle Lagrangian Integrated Trajectory) model, http://www.arl.noaa. gov/ready/hysplit4.html, NOAA Air Resources Laboratory, Silver, Spring, MD, 2003.

Ganguly, D., Jayaraman, A., and Gadhavi, H.: In situ ship cruise measurements of mass concentration and size distribution of aerosols over Bay of Bengal and their radiative impacts, J. Geophys. Res., 110, D06205, doi:10.1029/2004JD005325, 2005.

Gautam, R., Hsu, N. C., Kafatos, M., and Tsay, S.-C.: Influences of winter haze on fog/low cloud over Indo-Gangetic plains, J. Geophys. Res., 112, D05207, doi:10.1029/2005JD007036, 2007.

Gautam, R., Hsu, C. N., and Lau, K.-M.: Premonsoon aerosol characterization and radiative effects over the Indo-Gangetic Plains: Implications for regional climate warming, J. Geophys. Res., 115, D17208, doi:10.1029/2010JD013819, 2010.

IPCC: Summary for Policymakers, in: Climate Change 2007. The Physical Science Basis. Contribution of Working Group I to the Fourth Assessment Report of the Intergovernmental Panel on Climate Change, edited by: Solomon, S., Qin, D., Manning, M., Chen, Z., Marquis, M., Averyt, K. B., Tignor, M., and Miller, H. L., Cambridge, UK and NY, USA, Cambridge University Press, 2007.

Jayaraman, A., Gadhavi, H., Ganguly, D., Misra, A., Ramachandran, S., and Rajesh, T.: Spatial variation in aerosol characteristics over central India observed during the February 2004 road campaign experiment, Atmos. Environ., 40, 6504-6515, 2006.

Kalapureddy, M. C. R. and Devara, P. C. S.: Characterization of pre-monsoon aerosols over oceanic regions around India. Atmos. Environ., 42(28), 6816-6827, 2008.

Kaskaoutis, D. G., Kalapureddy, M. C. R., Krishna Moorthy, K., Devara, P. C. S., Nastos, P. T., Kosmopoulos, P. G., and Kambezidis, H. D.: Heterogeneity in pre-monsoon aerosol types over the Arabian Sea deduced from ship-borne measurements of spectral AODs, Atmos. Chem. Phys., 10, 4893-4908, doi:10.5194/acp-10-4893-2010, 2010.

Kaskaoutis, D. G., Kumar Kharol, S., Sinha, P. R., Singh, R. P., Kambezidis, H. D., Rani Sharma, A., and Badarinath, K. V. S.: Extremely large anthropogenic-aerosol contribution to total aerosol load over the Bay of Bengal during winter season, Atmos. Chem. Phys., 11, 7097-7117, doi:10.5194/acp-11-70972011, 2011.

Kedia, S. and Ramachandran, S.: Latitudinal and longitudinal variation in aerosol characteristics from sun photometer and MODIS over the Bay of Bengal and Arabian Sea during ICARB, J. Earth Syst. Sci., 117(S1), 375-387, 2008.

Kumar, A., Sarin, M. M., and Srinivas, B.: Aerosol iron solubility over Bay of Bengal: role of anthropogenic sources and chemical processing, Marine Chem., 121, 167-175, 2010.

Lawrence, M. G. and Lelieveld, J.: Atmospheric pollutant outflow from southern Asia: a review, Atmos. Chem. Phys., 10, 1101711096, doi:10.5194/acp-10-11017-2010, 2010.

Levy, R. C., Remer, L. A., Mattoo, S., Vermote, E., and Kaufman, Y. J.: Second-generation operational algorithm: Retrieval of aerosol properties over land from inversion of Moderate Resolution Imaging Spectroradiometer spectral reflectance, J. Geophys. Res., 112, D13211, doi:10.1029/2006JD007811, 2007. 
Liu, Z., Liu, D., Huang, J., Vaughan, M., Uno, I., Sugimoto, N., Kittaka, C., Trepte, C., Wang, Z., Hostetler, C., and Winker, D.: Airborne dust distributions over the Tibetan Plateau and surrounding areas derived from the first year of CALIPSO lidar observations, Atmos. Chem. Phys., 8, 5045-5060, doi:10.5194/acp-85045-2008, 2008.

Menon, S., Koch, D., Beig, G., Sahu, S., Fasullo, J., and Orlikowski, D.: Black carbon aerosols and the third polar ice cap, Atmos. Chem. Phys., 10, 4559-4571, doi:10.5194/acp-10-4559-2010, 2010.

Mian Chin, Diehl, T., Dubovik, O., Eck, T. F., Holben, B. N., Sinyuk, A., and Streets, D. G.: Light absorption by pollution, dust, and biomass burning aerosols: a global model study and evaluation with AERONET measurements, Ann. Geophys., 27, 3439-3464, doi:10.5194/angeo-27-3439-2009, 2009.

Moorthy, K. K. and Babu, S. S.: Aerosol black carbon over Bay of Bengal observed from an island location, Port Blair: Temporal features and long-range transport, J. Geophys. Res., 111, D17205, doi:10.1029/2005JD006855, 2006.

Moorthy, K. K., Babu, S. S., and Satheesh, S. K.: Aerosol spectral optical depths over Bay of Bengal: Role of transport, Geophys. Res. Lett., 30, 1249, doi:10.1029/2002GL016520, 2003.

Moorthy, K. K., Suresh Babu, S., and Satheesh, S. K.: Aerosol characteristics and radiative impacts over the Arabian Sea during the intermonsoon season: Results from ARMEX filed campaign, J. Atmos. Sci., 62, 192-206, 2005.

Moorthy, K. K., Satheesh, S. K., Babu, S. S., and Dutt, C. B. S.: Integrated Campaign for Aerosols, gases and Radiation Budget (ICARB): An overview, J. Earth Syst. Sci., 117(S1), 243-262, 2008.

Moorthy, K. K., Nair, V. S., Babu, S. S., and Satheesh, S. K.: Spatial and vertical heterogeneities in aerosol properties over oceanic regions around India: Implications for radiative forcing, Q. J. Roy. Meteorol. Soc., 135, 2131-2145, 2009.

Moorthy, K. K., Beegum, N. S., Suresh Babu, S., Smirnov, A., John, R. S., Raghavendra Kumar, K., Narasimhulu, K., Dutt, C. B. S., and Nair, V. S.: Optical and physical characteristics of Bay of Bengal aerosols during W-ICARB: Spatial and vertical heterogeneities in the MABL and in the vertical column, J. Geophys. Res., 115, D24213, doi:10.1029/2010JD014094, 2010.

Morys, M., Mims III, F. M., Hagerup, S., Anderson, S. E., Baker, A., Kia, J., and Walkup, T.: Design calibration, and performance of MICROTOPS II handheld ozone monitor and Sun photometer, J. Geophys. Res., 106(D13), 14573-14582, 2001.

Nair, V. S., Moorthy, K. K., Babu, S. S., and Satheesh, S. K.: Optical and physical properties of atmospheric aerosols over the Bay of Bengal during ICARB, J. Atmos. Sci., 66, 2640-2658, 2009.

Nair, V. S., Satheesh, S. K., Moorthy, K. K., Babu, S. S., Nair, P. R., and George, S. K.: Surprising observation of large anthropogenic aerosol fraction over the 'near-pristine' southern Bay of Bengal: Climate implications, J. Geophys. Res., 115, D21201, doi:10.1029/2010JD013954, 2010.

Patadia, F., Gupta, P., and Christopher, S. A.: First observational estimates of global clear sky shortwave aerosol direct radiative effect over land, Geophys. Res. Lett., 35, L04810, doi:10.1029/2007GL032314, 2008.

Powell, K. A., Hostetler, C. A., Vaughan, M. A., Lee, K. P., Trepte, C. R., Rogers, R. R., Winker, D. M., Liu, Z., Kuehn, R. E., Hunt, W. H., and Young, S. A.: CALIPSO Lidar calibration algorithms:
Part I - Nighttime 532-nm parallel channel and 532-nm perpendicular channel, J. Atmos. Ocean Technol., 26, 2015-2033, 2009.

Prasad, A. K., Yang, K.-H. S., El-Askary, H. M., and Kafatos, M.: Melting of major Glaciers in the western Himalayas: evidence of climatic changes from long term MSU derived tropospheric temperature trend (1979-2008), Ann. Geophys., 27, 4505-4519, doi:10.5194/angeo-27-4505-2009, 2009.

Ramachandran, S.: Spectral aerosol optical characteristics during the northeast monsoon over the Arabian Sea and the tropical Indian Ocean: 1. Aerosol optical depths and their variabilities, J. Geophys. Res., 109, D19207, doi:10.1029/2003JD004476, 2004.

Ramachandran, S., Rengarajan, R., Jayaraman, A., Sarin, M. M., and Das, S. K.: Aerosol radiative forcing during clear, hazy, and foggy conditions over a continental polluted location in north India, J. Geophys. Res., 111, D20214, doi:10.1029/2006JD007142, 2006.

Ramanathan, V., Crutzen, P. J., Lelieveld, J., Mitra, A. P., Althausen, D., Anderson, J., Andreae, M. O., Cantrell, W., Cass, G. R., Chung, C. E., Clarke, A. D., Coakley, J. A., Collins, W. D., Conant, W. C., Dulac, F., Heintzenberg, J., Heymsfield, A. J., Holben, B., Howell, S., Hudson, J., Jayaraman, A., Kiehl, J. T., Krishnamurti, T. N., Lubin D., McFarquhar, G., Novakov, T., Ogren, J. A., Podgorny, I. A., Prather, K., Priestley, K., Prospero, J. M., Quinn, P. K., Rajeev, K., Rasch, P., Rupert, S., Sadourny, R., Satheesh, S. K., Shaw, G. E., Sheridan, P., and Valero, F. P. J.: Indian Ocean Experiment: An Integrated analysis of the climate forcing and effects of the great Indo-Asian haze, J. Geophys. Res., 106, 28371-28398, 2001.

Ramanathan, V., Chung, C., Kim, D., Bettge, T., Buja, L., Kiehl, J. T., Washington, W. M., Fu, Q., Sikka, D. R., and Wild, M.: Atmospheric brown clouds: Impacts on South Asian climate and hydrological cycle, Proc. Natl. Acad. Sci. USA, 102, 5326-5333, 2005.

Reddy, M. S. and Venkataraman, C.: Inventory of aerosol and sulphur dioxide emission from India : II-Biomass combustion, Atmos. Environ., 36, 699-712, 2002.

Satheesh, S. K., Moorthy, K. K., and Das, I.: Aerosol spectral optical depths over the Bay of Bengal, Arabian Sea and Indian Ocean, Current Science, 81, 1617-1625, 2001.

Satheesh, S. K., Vinoj, V., Suresh Babu, S., Krishna Moorthy, K., and Nair, Vijayakumar S.: Vertical distribution of aerosols over the east coast of India inferred from airborne LIDAR measurements, Ann. Geophys., 27, 4157-4169, doi:10.5194/angeo-274157-2009, 2009.

Shaw, G. E.: Error analysis of multiwavelength sun photometry, Pure Appl. Geophys., 114, 1-14, 1976.

Singh, R. P., Dey, S., Tripathi, S. N., Tare, V., and Holben, B.: Variability of aerosol parameters over Kanpur, northern India, J. Geophys. Res., 109, D23206, doi:10.1029/2004JD004966, 2004.

Sinha, P. R., Manchanda, R. K., Kaskaoutis, D.G., Sreenivasan, S., Krishna Moorthy, K., and Suresh Babu, S.: Spatial heterogeneities in aerosol size distribution over Bay of Bengal during Winter-ICARB Experiment, Atmos. Environ., 45, 4695-4705, doi:10.1016/j.atmosenv.2011.04.085, 2011a.

Sinha, P. R., Manchanda, R. K., Subbaro, J. V., Dumka, U. C., Sreenivasan, S., Suresh Babu, S., and Moorthy, K. K.: Spatial distribution and vertical structure of the MABL aerosols over the Bay of Bengal during winter: results from W-ICARB experi- 
ment, J. Atmos. Solar Terr. Phys., 73, 430-438, 2011 b.

Smith, S. R., Bourassa, M. A., and Sharp, R. J.: Establishing more truth in true winds, J. Atmos. Oceanic Technol., 16, 939-952, 1999.

Sreekanth, V., Krishna Moorthy, K., Satheesh, S. K., Suresh Babu, S., Nair, Vijayakumar S., and Niranjan, K.: Airborne measurements of aerosol scattering properties above the MABL over Bay of Bengal during W_ICARB - characteristics and spatial gradients, Ann. Geophys., 29, 895-908, doi:10.5194/angeo-29-8952011, 2011.

Sumanth, E., Mallikarjuna, K., Stephen, J., Moole, M., Vinoj, V., Satheesh, S. K., and Moorthy, K. K.: Measurements of aerosol optical depths and black carbon over Bay of Bengal during post-monsoon season, Geophys. Res. Lett., 31, L16115, doi:10.1029/2004GL020681, 2004.

Venkataraman, C., Habib, G., Eiguren-Fernandez, A., Miguel, A. H., and Friedlander, S. K.: Residential biofuels in South Asia: carbonaceous aerosol emissions and climate impacts, Science, 307, 1454-1456, 2005.
Venkataraman, C., Habib, G., Kadamba, D., Shrivastava, M., Leon, J. F., Crouzille, B., Boucher, O., and Streets, D. G.: Emissions from open biomass burning in India: Integrating the inventory approach with high-resolution Moderate Resolution Imaging Spectroradiometer (MODIS) active-fire and land cover data, Global Biogeochem. Cycles, 20, GB2013, doi:10.1029/2005GB002547, 2006.

Vinoj, V., Suresh Babu, S., Satheesh, S. K., Moorthy, K. K., and Kaufman, Y. J.: Radiative forcing by aerosols over the Bay of Bengal region derived from shipborne, island-based, and satellite (Moderate-Resolution Imaging Spectroradiometer) observations, J. Geophys. Res., 109, D05203, doi:10.1029/2003JD004329, 2004.

Yu, H., Kaufman, Y. J., Chin, M., Feingold, G., Remer, L. A., Anderson, T. L., Balkanski, Y., Bellouin, N., Boucher, O., Christopher, S., DeCola, P., Kahn, R., Koch, D., Loeb, N., Reddy, M. S., Schulz, M., Takemura, T., and Zhou, M.: A review of measurement-based assessments of the aerosol direct radiative effect and forcing, Atmos. Chem. Phys., 6, 613-666, doi:10.5194/acp-6-613-2006, 2006. 